\title{
Angiotensin I-Converting Enzyme Inhibitory Activity of Enzymatic Hydrolysates of Whey Milk, Casein and Egg Albumin by Microbial Enzymes and a Commercial Enzyme
}

\author{
Y.A.A. Hamin-Neto and H. Cabral \\ Department of Pharmaceutical Sciences, School of Pharmaceutical Sciences of Ribeirao Preto, University of \\ Sao Paulo, do Café Avenue, Ribeirao Preto, 14040-903, Brazil
}

\section{Introduction}

Hydrolases, particularly proteases, are among the most widely sold enzymes [1]. These enzymes represent approximately $60 \%$ of the enzymes sold worldwide [1]. Proteases can be used in different industrial sectors, such as food, detergents, leather, medicines [2], bioremediation [3], and in production of bioactive peptide by enzymatic proteolysis of milk proteins [4]. Bioactive peptides are peptides that have activities similar to drugs or hormones, modulating physiological functions by interacting with specific receptors on target cells inducing answers [5]. Bioactive peptides have emerged on the market in the 70s, when Novartis launched Lypressin ${ }^{\circledR}$, an analogue of vasopressin. Hypertension affects about one quarter of the world population, it is a major risk factor for cardiovascular disease and related complications [5,6]. The angiotensin I-converting enzyme (ACE) catalyses the conversion of angiotensin I to angiotensin II, a potent vasoconstrictor and has an important role in regulating blood pressure in mammals [6]. Inhibitor peptides of ACE were released from milk casein and whey proteins from goat milk by use of two commercial enzymes subtilisin (Alcalase 2.4 L FG, EC 3.4.21.62) and pancreatic trypsin (PTN 6.0 S Salt free; EC 3.4. 21.4) [7]. The aim of this study was to obtain peptides produced from egg albumin, casein and whey protein, by action of two microbial enzymes and a commercial enzyme, and to evaluate the inhibition of angiotensin I-converting enzyme using fluorescent substrate (Abz-FRK(Dnp)P-OH) in the presence of these hydrolysates.

\section{Results and discussion}

Protein hydrolysates were obtained from egg albumin, casein and whey protein. Enzymes, isolated from submerged extract of fungi Eupenicillium javanicum and Myceliophtora thermophila and commercial trypsin (Sigma-Aldrich ${ }^{\circledR}$ ), were used to proteolysis. The hydrolysates were evaluated to ACE inhibitory activity using a synthetic FRET (fluorescence resonance energy transfer) peptide substrate (Abz-FRK(Dnp)P-OH), specific to this enzyme. The reaction occurred in spectrofluorimeter,

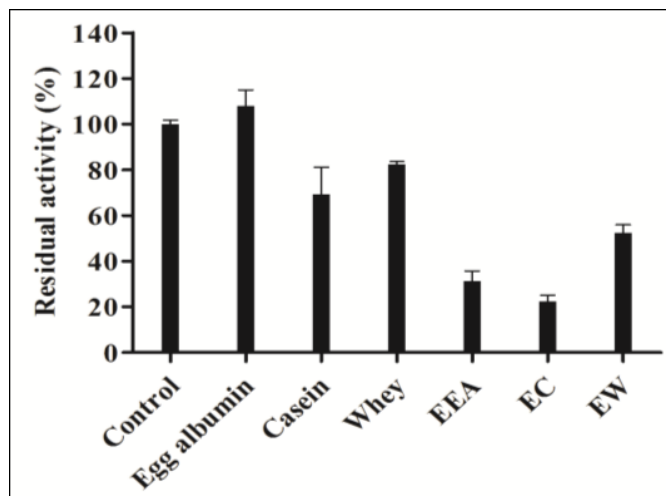

Fig. 1. ACE inhibitory activity of protein and their hydrolysates $(0.8 \mathrm{mg} / \mathrm{mL})$ produced from egg albumin (EEA), casein (EC) and whey protein (EW), using an enzyme produced by the fungus Eupenicillium javanicum. The test was conducted with ACE (Sigma-Aldrich $\left.{ }^{\circledR}\right)$ in spectrofluorometer, $\mathrm{pH} 7.0$ at $37^{\circ} \mathrm{C}$ with a synthetic FRET peptide substrate (Abz-FRK(Dnp) $\mathrm{P}-\mathrm{OH})$. 
Lumina fluorescence spectrometer (Thermo Scientific) at $37^{\circ} \mathrm{C}$. The hydrolysates, produced by action of Eupenicillim javanicum enzyme, showed ACE inhibitory activity from all substrates, egg albumin (EEA), casein (EC) and whey protein (EW) were able to inhibit the ACE, about 70, 80, and 50\%, respectively (Figure 1).

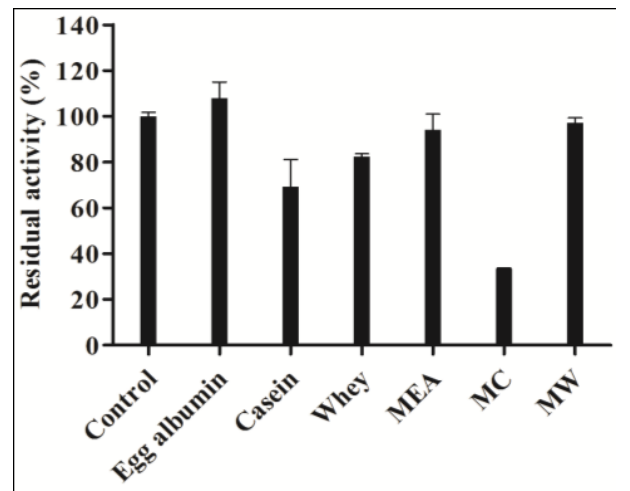

Fig. 2. ACE inhibitory activity of protein and their hydrolysates $(0.8 \mathrm{mg} / \mathrm{mL})$ produced from egg albumin (MEA), casein $(M C)$ and whey protein $(M W)$, using an enzyme produced by the fungus Myceliophthora thermophila. The test was conducted with ACE (Sigma-Aldrish $\left.{ }^{\circledR}\right)$ in spectrofluorometer, pH 7.0 at $37^{\circ} \mathrm{C}$ with a synthetic FRET peptide substrate (Abz-FRK(Dnp)P-OH).

Analyzing the results of hydrolysates produced by Myceliophthora thermophila, only the products of casein cleavage were able to inhibit the ACE activity, about $70 \%$ (Figure 2).

The results of hydrolysates produced by commercial trypsin were similar to Myceliophthora thermophila enzyme, only products derived from casein hydrolyses presented capacity to inhibit the ACE enzyme, about $85 \%$ (Figure 3).

The hydrolysates from all substrates produced in the presence of the enzyme from the fungus Eupenicillium javanicum and casein hydrolysates produced by enzymes, from fungus Myceliophthora thermophila and trypsin, were able to inhibit angiotensin I-converting enzyme. Each enzyme presents a specificity and affinity to substrates. These characteristics define the capacity to cleave the substrate and the cleavage site. The positions of hydrolysis are related to peptides sequences produced, and these amino acids sequences and its physics and chemistry characteristics are directly linked with the biological activity.

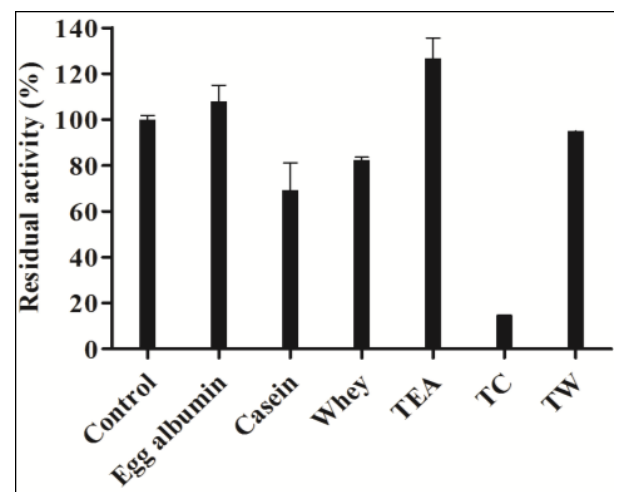

Fig. 3. ACE inhibitory activity of proteins and their hydrolysates $(0.8 \mathrm{mg} / \mathrm{mL})$ produced from egg albumin (TEA), casein (TC) and whey protein (TW), using an enzyme commercial trypsin (SigmaAldrich $\left.{ }^{\circledR}\right)$. The test was conducted with ACE (Sigma-Aldrich $\left.{ }^{\circledR}\right)$ in spectrofluorometer, pH 7.0 at $37^{\circ} \mathrm{C}$ with a synthetic FRET peptide substrate (Abz-FRK(Dnp)P-OH). 
According to $\mathrm{Li}$ and $\mathrm{Yu}$ (2015), the catalytic site of ACE has three amino acids that are corresponding to hydrophobic amino acids from angiotensin I in $C$-terminal, only when the amino acids of bioactive peptides interact with these subunits, they can present inhibitory activity. The sequence of three amino acids in the $C$-terminal influences this inhibition. Aromatic or alkaline amino acids in the $N$-terminal improve the inhibitory activity. Leucine, isoleucine and valine in the $N$-terminal influence positively in the inhibitory activity, while proline in this position influences negatively. According to the results, the used proteins derived in products that showed potential application as ACE enzyme inhibitors, other studies are necessary to isolate and to sequence the peptides that presented activity.

\section{Acknowledgements}

The authors would like to acknowledge financial support provided by Fundação de Amparo à Pesquisa do Estado de São Paulo, (FAPESP) (2012/18278-2, 2012/24703-8 and 2011/06986-0 process) and Conselho Nacional de Desenvolvimento Científico e Tecnológico, CNPq, (308078/2012-8 process).

\section{References}

1. Rao, M.B., et al. Microbiol. Mol. Biol. Rev. 62, 597-635 (1998).

2. Rai, S.K., Mukherjee, A.K. Biochem. Eng. J. 54, 47-56 (2011), http://dx.doi.org/10.1016/i.bei.2011.01.007

3. Gupta, R., et al. Appl. Microbiol. Biotechnol. 60, 381-395 (2002), http://dx.doi.org/10.1007/s00253-002$1142-1$

4. Korhonen, H. J. Funct. Foods 1, 177-187 (2009), http://dx.doi.org/10.1016/j.jff.2009.01.007

5. Fitzgerald, R., Murray, B. Int. J. Dairy Technol. 59, 118-125(2006).

6. Hartmann, R. Meisel, H. Curr. Opin. Biotechnol. 18, 163-169(2007), http://dx.doi.org/10.1016/j.copbio.2007.01.013

7. Espejo-Carpio, F., et al. Int. Dairy J. 32, 175-183(2013).

8. Li, Y., Yu, J. J. Med. Food 18(2), 147-156(2015), http://dx.doi.org/10.1089/jmf.2014.0060 